American Journal of Applied Sciences 7 (8): 1032-1037, 2010

ISSN 1546-9239

(C) 2010 Science Publications

\title{
Impact Assessment and Utilization of Eastern Redcedar
}

\author{
Difei Zhang and Salim Hiziroglu \\ Department of Natural Resource Ecology and Management, \\ Agricultural Hall Room 008C, Oklahoma State University, \\ Stillwater, Oklahoma 74078-6013, USA
}

\begin{abstract}
Problem statement: The fast invasion of eastern redcedar (Juniperus virginiana L.) has been considered a significant problem to the environment and rural communities. Approach: This study examined the adverse ecological and economic impacts of eastern redcedar and proposed the sustainable development of value-added panel products from such under-utilized invasive species. Also what economic sectors were mostly influenced was examined. Additionally experimental panels were manufactured from low quality eastern redcedar trees. Results: Both physical and mechanical characteristics of experimental panels were found to be satisfactory and comparable to those of typical commercial panels made from other species. It appears that average modulus of elasticity value of the samples with two density levels had 9\% higher than that of a typical commercially produced panels. Conclusion: The importance of this study is expansion of the use of low quality eastern redcedar in value-added composite panel manufacture which seems an alternative solution in the development of an environmentally sound and economically effective way to utilize such resource.
\end{abstract}

Key words: Eastern redcedar, impact assessment, invasive species, value-added panel products

\section{INTRODUCTION}

Eastern redcedar (Juniperus virginiana L.) is one of widely distributed species in Oklahoma with an estimated current area covered beyond 9 million acres. It is expected that such resource will reach to 13 million acres by 2013 at a growth rate of 762 acres per day resulting in a significant adverse impact on ecology (Bidwell et al., 1996; Philips, 2005). The largest areas of recent expansion have been in the southwestern part of the state, characterized by an arid climate and rocky soils and the northwestern part of the state; primarily open prairie land dissected by waterways. It is concerned that encroaching redcedar may someday capture over the tall grass prairies in northern Oklahoma. Eastern redcedar is a problem to farmers and ranchers who often lose crop and pasture land to the species. The trees are generally considered a waterstealing and space-taking nuisance. Many wildlife species that require open range also are adversely affected by this species. Currently the wood from eastern redcedar is used for fence posts and novelty items, while the species maybe planted for shelterbelts and windbreaks.
Overall the wood products industry makes a significant contribution to Oklahoma's Economy. While Oklahoma is lack of non-traditional market for low grade small material wood products, fully utilizing the economic potential of the eastern redcedar by expanding the use of the low grade logs in value-added products can reduce the adverse economic impact of this invasive species native to Oklahoma.

There will be substantial economic impact which will occur due to the development of value-added panel products industries from the under-utilized invasive local species of eastern redcedar and examine in what economic sectors the effects would be most noticed. The magnitude of economic impacts resulting from such changes in manufacturing panel products can be quantified and analyzed under current market structures as well as the biological factors associated with this under-utilized invasive local species of eastern redcedar.

Previous work: A few attempts have been made to look into the various aspects of redcedar and how this can be effectively put into use in an environmentally friendly manner and for the cause towards an energy safe world.

Corresponding Author: Difei Zhang, Department of Natural Resource Ecology and Management, Agricultural Hall Room 008C, Oklahoma State University, Stillwater, Oklahoma 74078-6013, USA Tel: 405-744-1965 
Oklahoma contains some of the oldest eastern redcedar trees in the entire south central United States. From a historical existence amidst rocky outcroppings and river creek drainages, this species spread fast to all parts of Oklahoma soon. Stritzke and Bidwell (1989) stated that the acres of rangeland under redcedar infestation problem increased from 1.5 million acres to over 3.5 million acres within a gap of 35 years from 1950-1980. Many years of fire suppression and seedling plantings are said to be one of the reasons for this fast encroachment to several parts. In the case of Oklahoma, strict liability law and social uneasiness with fire limited the practice of burning and further accelerated the infestation of junipers. Also, the ability of redcedar to withstand variations in soils and climatic extremes and its ability to thrive on soils that are low in nutrients and high genetic variability increased their survival and accelerated the spread.

Redcedar infestation problems started in Oklahoma only after initial settlement. Within a short span of time, Oklahoma's native forests, rangelands, pastures and prairies have been infested with redcedar and other junipers. The estimates of USDA Natural Resources Conservation Service (1976) (NRCS) state that 8 million acres in Oklahoma are currently infested with at least 50 juniper trees per acre. These estimates further state that the encroachment is increasing at an estimated rate of 750 acres a day or nearly 300,000 acres per year as mentioned previously. An estimated 8 million acres of prairies and crosstimber habitat in Oklahoma has been already invaded by redcedars and junipers. Furthermore, it is expected that the amount of infestation will double every 18 years. It is estimated that almost 12.6 million acres in Oklahoma will be invaded by eastern redcedar by 2013 . This points that $28 \%$ of the landscape in Oklahoma will be under the infestation of junipers by 2013.

Such significant ecological problem poses various threats to the environment, the farmers and rangelands. In July, 2002, the NRCS state technical committee declared Juniper encroachment as Oklahoma's number one natural resource concern. The rapid spread of red cedar and Juniper species has been one of the serious concerns among the landowners, scientists and policy makers of Oklahoma.

Ecological impact analysis: Eastern redcedar has volatile oil in its anatomy which increases the fire risk. The complications from weather conditions such as wind and drought in Oklahoma, makes eastern redcedar problem more complex. The increased juniper infestation within the areas where humans interact with environment has resulted in a potential increase of catastrophic wildfires. Cross timbers post oak and blackjack oak forests becomes very susceptible to wildfires if the understory is of junipers. The safety risk to firefighters has increased due to the increased infestation of redcedar and other juniper species. Economic loss and the cost of suppressing these fires are immense and can cause considerable losses to the government and the public. Educating rural and urban interface residents about junipers and their increased risk to wildfire is a real challenge. Homeowners who appreciate the greenery and believe that "tree is good", mostly do not recognize the increased fire risk from these highly flammable trees growing near them. The homes built in the wild land/urban interface may not be under the jurisdiction of a city or a town. This can cause an increased emergency response time in these areas and can cause much more catastrophes. Although this threat has been addressed by several agencies and scientists, is still a latent problem.

The invasion of highly tolerant and competent redcedar has displaced many native species which are less competitive but ecologically significant. Biological diversity has been largely reduced with the infestation of junipers as a result of the reduction in the number of living organisms, their functions and interactions (Bidwell et al., 1996). The reduction in patch size and fragmentation of plant communities creating ecosystem dysfunction (Coppedge et al., 2002) is another detrimental effect. In riparian zones, undesirable changes in stream flow dynamics, biological diversity, wildlife habitat and forage production (Cooper et al., 1998) have been reported due to invasion of exotic plants.

Due to various changes occurred in the habitat and surroundings caused due to invasive redcedars, many changes have been reported in the wildlife species. Various researchers have attempted to study this effect. Change in habitat structure and composition was found where invasion happened and resulted in some wildlife species displacement (Bidwell et al., 1996). Smith (2001) reported that redcedar infestation in turkey roost sites has displaced the entire turkey flock. Coppedge et al. (2002) found out that only $25 \%$ of juniper cover presence was sufficient to take grassland bird abundance and richness to nonexistence. At current invasion rate of eastern redcedar, Oklahoma could be losing up to 5,680 bobwhite quail covers per year (Guthery, 2001). Many grassland birds and songbirds from the native prairie have been displaced and the major reason behind this was high juniper content.

Reduction in the livestock/forage production is one of the most serious threats posed by invading redcedar. Stritzke and Bidwell (1989) stated that a juniper tree with a six-foot crown diameter on a shallow prairie 
range site will reduce forage by about six pounds. If left untreated, junipers will reduce forage production. Engle et al. (1987) showed that within a gap of 10 years, in an unmanaged range site, potential of livestock production can decrease to almost half. The invasion of rangelands by redcedars has resulted in reduced stocking rates and carrying capacity (Bidwell et al., 1996). Reduced pasture visibility and increased labor during livestock handling are also negative impacts associated with livestock/forage production. Juniper encroachment is also assumed to have role in water quality reduction. The early studies by Thurow and Carlson (1994) reported that Juniper encroachment degrades watershed quality by increasing the amount of bare soil and increasing the potential for erosion. Their study also stressed on the extensive root system possessed by junipers and the resulting "water wastage" when the supply of soil water is not limited. The aggressive competition from these hardened trees affect indigenous species in riparian and streamside areas and may drastically change ecological communities and reduce natural diversity within the riparian zone (Cooper et al., 1998). One of the most serious problems due to the increased infestation of redcedars, which directly affects human beings, is the pollen. The additional pollen created by increased infestation cause allergic reactions and asthma type health problems in humans. Burning vegetation causes emissions of many different chemical compounds, including gases and particulate matter which may pose serious threat to human life.

Certain wood products from redcedar and other junipers have economic value. Eastern redcedar has a long history as a valuable lumber commodity. Deep red heartwood of redcedar has been valued for its rot resistance and for its beauty for over 3,000 years. Within the industry, the numerous knots present in the cedar wood are considered one of the attractive features. This lumber is rarely used for its structural strength, but rather for its beauty and for its anti-fungal and anti-microbial qualities in resisting rot. Also, the heartwood of a mature tree can be processed for the oil content, yielding cedar oil, which is used in perfumes as a fixative and is fairly valuable. The evergreen nature of eastern redcedar has also its existence value in terms of its aesthetical beauty.

The redcedar task force final report came up with a list of potential products from redcedar including Solid Wood Products/Large Tree Use and Fiber Products/Whole Tree Use. Of these various products, several have been considered under serious investigation including the production of particleboard using eastern redcedar whole tree chips. Hiziroglu and
Holcomb (2005) examined some properties of threelayer particleboard made from redcedar. The results showed that average physical and mechanical properties of the panels were comparable to those of commercial particleboard manufactured from other species. Hiziroglu (2009) also examined the properties of strandboard panels manufactured from redcedar. The results showed that the mechanical properties of the panels improved with density. It was concluded that eastern redcedar, which is an under-utilized invasive resource, has potential as a raw material for structural panel manufacture in the study (Hiziroglu, 2009). Therefore the objective of this work analyzes the impact of using redcedar in the form of value-added panels and its assessment.

\section{MATERIALS AND METHODS}

Low quality eastern redcedar trees with an average diameter breast height of 5 inch were harvested in Oklahoma. A commercial chipper was used to convert trees into chips and these chips then were reduced to particles using a hammermill by a local wood products manufacturer. The whole-tree furnish was dried to $5 \%$ moisture content in a laboratory oven prior to the blending process in mixing drum. An average of $10 \%$ urea formaldehyde based on the oven dry weight of particles was used. Twenty single-layer boards in $20 \times 20 \times 0.5$ inch were pressed using a pressure of $750 \mathrm{psi}$ and a temperature of $355^{\circ} \mathrm{F}$ for $6 \mathrm{~min}$. Target board densities were 0.65 and $0.75 \mathrm{~g} \mathrm{~cm}^{-3}$ for the panels.

Samples from conditioned panels were cut for various tests. Density of whole panels and sample were also calculated. Thickness swelling, water absorption, modulus of elasticity, modulus of rupture, internal bond strength and screw holding samples were cut from each individual panel based on the ASTM D-1037 standard. Com-Ten Universal testing unit with 2,000 lbs load cell capacity were employed for mechanical tests.

Economic impact analysis: All these problems mentioned above related to redcedar invasion can ultimately lead to significant economic losses due to cost of not controlling and cost of controlling eastern redcedar in Oklahoma.

In 2001, an estimated $\$ 52$ million was lost in lease hunting due to redcedar invasion and the loss of forage production was estimated to be $\$ 100$ million. The annual economic loss in an average year in 2001 for catastrophic wildfire, loss of cattle forage, loss of wildlife habitat (lease hunting), recreation and water yield was estimated to be $\$ 218$ million. The economic 
situation can get worse in Oklahoma if junipers are not effectively managed. The cost of controlling juniper increases as the canopy density increases from low to high. The loss of property, costs of fighting wildfires and increase in insurance premiums can all be resulted if proper measures are not taken in time. There are other losses which cannot be quantified including potential loss of endangered species, poor water quality, sedimentation in water reservoirs and degraded air quality.

Ecosystem maintenance and ecosystem restoration methods can also cost millions. Ecosystem restoration, which is the conversion of stands of redcedar and other junipers back to native plant communities, requires intensive high-cost inputs. The benefits from eastern redcedar have not been dealt in detail. However, redcedars if effectively utilized can be an excellent source of revenue for the government and landowners and bring in net social benefits. In small amounts, junipers can be beneficial for woodland wildlife. Thermal and loafing cover for wildlife can be obtained from dense stands of junipers. But the value of junipers for wildlife habitat is very limited. Stritzke and Bidwell (1989) stated that small areas of junipers can be an important cover resource for wildlife. Redcedars and other junipers are often used as windbreaks in farmlands. This can cut home heating costs, reduce the amount of dust entering a home and protect a home from snow drifting. The junipers used as windbreaks help in the reduction of wind erosion, increase soil moisture, provide livestock and wildlife protection, provide some wildlife species an additional food resource, reduce the drying effect of wind on soil and plants and prevent the abrasive action of rapidly moving soil particles on young plants.

Biomass industry is another potential field. A 1993 study on the pinyon pine and juniper stands of eastern Nevada (Morris, 1993) reviewed the potential opportunities to use biomass very similar to Oklahoma's junipers for pellet fuels or electric power. The study revealed limitations in using these fuels for pellets because of the high ash content. The final report of the redcedar task force states that, just to break even with the current rate of infestation, junipers are to be controlled in an estimated 30,000 acres per year. Aggressive treatment is required in 2-4 million acres per year to restore lands from encroachment and for maintenance. Task force report did not indicate that juniper encroachment was wholly unacceptable but stress the term proper management

A large potential market for the value-added particleboard panels production from whole-tree furnish of eastern redcedar can be created while changes in Oklahoma wood products consumption and international trade have shifted timber demand. Closure of pulp and paper mills has influenced the spatial arrangement of timber markets which has adversely impacted Oklahoma local economy.

This value-added panel market from this abundant invasive species in Oklahoma can grow to be a largescale divestiture of wood products industry. It will be an important factor in shaping supply and demand as substitution effects become evident in the inelastic wood product market. Small business firms can be developed to produce such panels from eastern redcedar with innovative technology.

The value-added wood products can be commercialized and continue to grow to establish a stable market with major consumer target zones. Longterm goal is to expand the domestic demand of valueadded panels from eastern redcedar in Oklahoma to a large-scale production by increasing more jobs and economic efficiency of such production. This market will promote the relationship between economic efficiency in non-traditional wood product market using invasive species and maximum economic welfare of the industry, the forest resource base and local communities in Oklahoma. Necessary conditions can be derived to achieve the maximum utility from the eastern redcedar in terms of Pareto Efficiency which is unable to increase the output of any one product without reducing the output of at least other product.

Opportunities for the development of such valueadded market by fully utilizing the economic potential of eastern redcedar will be emerging with the growing incentives from the private forest landowners in Oklahoma to keep their land in healthy forest cover and contribute to improve ecosystem services and biodiversity by making use of the eastern redcedar trees instead of simply burning it. It will provide new opportunities for local and interstate investment and employment.

\section{RESULTS AND DISCUSSION}

Based on the experimental part of this work both mechanical and physical properties of the panels made from eastern redcedar are presented in Table 1, Average MOE, MOR and IB for eastern redcedar samples were $333,869,2,249$ and 178 psi, respectively. Two previous study found that MOE and MOR of whole-tree chip particleboard samples ranged from 329,651-233,450 psi and 1,848-1,612 psi (Hiziroglu and Holcomb, 2005) Based on ANSI A 28.1 250,200, 1,595 and 58 psi are minimum requirements for MOE, MOR and IB of particleboard panels for M-1 grade, respectively (American Society for Testing and Materials, 1996). 
Am. J. Applied Sci., 7 (8): 1032-1037, 2010

Table 1: Average values of static bending (MOE and MOR) and Internal Bond strength (IB) properties of single layer board as compared to those of commercial particleboard

\begin{tabular}{lccrr}
\hline & Type A & Type B & Type C & Typical commercially \\
Test name (psi) & $0.65 \mathrm{~g} \mathrm{~cm}^{-3}$ & $0.75 \mathrm{~g} \mathrm{~cm}^{-3}$ & $0.65 \mathrm{~g} \mathrm{~cm}^{-3}$ & produced particleboard \\
\hline MOE & 346,386 & 364,571 & 290,651 & 322,625 \\
MOR & 2,344 & 2,557 & 1,848 & 2,200 \\
IB & 172 & 214 & 148 & 116 \\
\hline
\end{tabular}

Note: Panels Types-A and B had furnish without foliage; Panel Type-C are with foliage

All types of panels satisfied the bending and IB strength requirements. It seems that foliage content in the furnish did not influence adversely mechanical properties of the samples.

The fast invasion of eastern redcedars has been considered detrimental to the environment and human beings. If we can properly manage these resources, it can generate great social economic welfare and sustainable environmental benefits. Further research in alternate energy sources, wood products and other economic opportunities from eastern redcedars needs to be conducted in great details.

The area of engineered wood products particularly wood composites has been identified as the fastest growing industry. Wood composition boards such as particleboard are commodity products manufactured in great quantities in the United States and are primarily used in the furniture and cabinet industries.

Another study related to resistance of eastern redcedar panels was carried out (Kard et al., 2007). Eastern redcedar particles and one in by one in square samples of single-layer panels with or without foliage and three-layer panels with foliage were exposed to termites. The specimens sustained some damage by feeding termites. All of the samples were not preferred simultaneously to termite. In no-choice feeding tests, where termites received only one panel product as a sole feeding source, all panel products sustained less feeding damage compared with Radiata pine. Also termite survival was less than $20 \%$ after 12 weeks compared with $84 \%$ survival in Radiata pine controls. In the choice tests where all particles and panel products were available at the same time, Radiata pine sustained $40.6 \%$ weight loss compared with weight loss ranging from $4.75-6.09 \%$ for the three types of sample products. In the no-choice tests these values were ranged from 4.75-6.62 and Radiata controls sustained $9.84 \%$ weight loss. Based on the initial findings in this study it appears that particleboard panels made from eastern redcedar could provide some benefit against termite damage.

\section{CONCLUSION}

Experimental part of this work revealed that both physical and mechanical properties of the panels were found to be comparable to those of made from other species reported in previous work (Hiziroglu and Holcomb, 2005) and (Cai et al., 2004). There are various parties interested in manufacturing such panels at small scale however currently there is no solid market study carried out about demand of particleboard panel in Oklahoma or any other states. The importance to expand the use of low quality eastern redcedar in composite panel manufacture may result in the development of an environmentally sound and economically effective way to utilize this resource. Converting this under-utilized invasive species in a value-added panel product will be very attractive for the wood products manufactures in Oklahoma. Future studies can address major needs of utilization of low quality eastern redcedar as raw material for particleboard and testing of the properties of such panels. Additionally eastern redcedar has approximately 3.5-3.8\% essential oil in heartwood which is used as insecticide and in fragrance industry. It is expected that when the resin is combined with oil in the particles insect resistance of the panel with attractive fragrance should be an important advantage of the final product. Panels also should result in better performance as underlayment, flooring and mobile home manufacturing where they are exposed to high humidity and moisture. Utilization of low quality eastern redcedar as raw material for the particleboard would provide as an alternate solution for such panels. In a long term, this could convert a costly forest and landscape management problem into marketable particleboard panels.

\section{ACKNOWLEDGEMENT}

This study is funded by USDA project OKLO2738 and USDA Forest Service Federal Financial Assistance Award. Assistance in funding from Robert M. Kerr Food and Agricultural Products Center (www.fapc.biz) is also acknowledged. 


\section{REFERENCES}

American Society for Testing and Materials, 1996. ASTM D1037-06a standard test method for evaluating the properties of wood based fiber and particle panel material. ASTM Standards. http://www.astm.org/Standards/D1037.htm

Bidwell, T.G., D.M. Engle, M.E. Moseley and R.E. Masters, 1996. Invasion of Oklahoma rangelands and forest by eastern redcedar and Ashe juniper. Oklahoma Cooperative Extension Service. http://pods.dasnr.okstate.edu/docushare/dsweb/Get/ Document-6627/E-947.pdf

Cai, Z., Q. Wu, J.N. Lee and S. Hiziroglu, 2004. Influence of board density, mat construction and chip type on performance of particleboard made from eastern redcedar. For. Prod. J., 54: 226-232. http://www.treesearch.fs.fed.us/pubs/21932

Cooper, M.S., T. Johnson and J. Dickey, 1998. Riparian Area Management Handbook. 1st Edn., Oklahoma Cooperative Extension Service, Oklahoma, pp: 110.

Coppedge, B.R., D.M. Engle, S.D. Fuhlendorf, R.N. Chapman and R.E. Masters et al., 2002. Juniper encroachment and avifaunal dynamics in Southern Great Plains grasslands: A multi-scale summary. Proceeding of the 17th Annual Symposium of the International Association for Landscape Ecology, (IALE'02), US Regional Association, Lincoln, Nebraska, pp: 1-1.

Engle, D.M., J.F. Strizke and P.L. Claypool, 1987. Herbage production around eastern redcedar trees. J. Range. Manage., 40: 237-239. http://www.jstor.org/pss/3899086

Hiziroglu, S., 2009. Properties of strandboard panels manufactured from eastern redcedar. Materials, 2: 926-933. DOI: 10.3390/ma2030926

Hiziroglu, S. and R. Holcomb, 2005. Some of the properties of three-layer particleboard made from eastern redcedar. Build. Environ., 40: 719-723. DOI: 10.1016/j.buildenv.2004.05.016
Hiziroglu, S. and R. Rabiej, 2005. Factors affecting adhesive shear strength of overlaid composite panel. Am. J. Applied Sci., Special Iss., 1: 1-4. http://www.scipub.org/fulltext/si/ajas_si_1-4.pdf

Kard, B.M., S. Hiziroglu and M.E. Payton, 2007. Resistance of eastern redcedar panels to damage by subterranean termites (Isoptera: Rhinotermitidae). For. Prod. J., 57: 74-79. http://cat.inist.fr/?aModele $=$ afficheN\&cpsidt $=1988$ 9532

Morris, G., 1993. Commercial feasibility analysis for fuels from pinyon-juniper biomass. Western Region Biomass Energy Program.

Philips, F.D., 2005. Sea of cedar. Natural Resources Conservation Service.

http://www.ok.nrcs.usda.gov/programs/misc/SeaOf Cedar.html

Smith, R., 2001. Your side of the fence landowner newsletter. Oklahoma Department of Wildlife Conservation.

http://www.wildlifedepartment.com/ysof/Vollissue 2.PDF

Stritzke, J.F. and T.G. Bidwell, 1989. Eastern redcedar and its control. Cooperative Extension Service. $\mathrm{http} / / /$ agris.fao.org/agrissearch/search/display.do?f=1990/US/US90240.xml ;US9036131

Thurow, T.L. and D.H. Carlson, 1994. Juniper effects on rangeland watersheds. Proceedings of the Juniper Symposium, Texas Agricultural Experiment Station, (JS'94), A\&M University Research Station, Sonora, Texas, pp: 31-43.

USDA Natural Resources Conservation Service, 1976. Technical notes: Farmstead and feedlot windbreak research. USDA. 